$\underline{\text { Article }}$

\title{
Copper(II) Mixed Ligands Complexes of Hydroxamic Acids with Glycine, Histamine and Histidine
}

\author{
Maria Celina M.M. Fernandes ${ }^{a}$, Eucler B. Paniago ${ }^{b}$, and Sandra Carvalho ${ }^{a}$ \\ ${ }^{a}$ Depto. de Química-ICEx, UFMG \\ ${ }^{b}$ Depto. de Química-ICEB, UFOP
}

Received: December 19, 1996

\begin{abstract}
Um estudo potenciométrico e espectrofotométrico de complexos mistos de $\mathrm{Cu}$, , fisiologicamente interessantes, foi realizado envolvendo ácidos hidroxâmicos como ligantes primários (A) e ligantes secundários (B) representados por histamina ou pelos aminoácidos glicina e histidina. Todos são potencialmente capazes de formar quelatos com anéis de cinco ou seis membros. A constante de formação e o espectro de absorção no visível são calculados para cada uma das espécies identificadas, tanto binárias quanto ternárias. As estruturas mais prováveis das espécies mistas são propostas com base nas constantes de formação calculadas, na estabilização em relação às duas espécies binárias correspondentes, bem como nos espectros de absorção no visível. Ficou comprovado que os complexos de $\mathrm{Cu}$-hidroxamato não favorecem significativamente a formação de complexos ternários com aminoácidos que possuem apenas os grupos amino e carboxilato; contudo, a formação de complexos ternários com a histidina é fortemente favorecida, devido à presença do grupo imidazol.
\end{abstract}

A potentiometric and spectrophotometric study of physiologically interesting $\mathrm{Cu}^{\mathrm{II}}$ mixed ligand complexes has been performed involving hydroxamic acids as primary ligands (A) and secondary ligands (B) represented either by histamine or the aminoacids glycine and histidine. All are potentially able to form chelate complexes with either five or six membered rings. The formation constant and the visible absorption spectrum were calculated for each one of the identified species, both binary and mixed ones. The most probable structures of the mixed species are discussed based upon their formation constants, their stabilization with regard to the two binary species as well as their visible absorption. It was evidenced that $\mathrm{Cu}$-hydroxamate complexes do not favour significantly mixed ligand complex formation with aminoacids having only the carboxylate and amino groups; however, these complexes are strongly formed with histidine, due to the presence of the imidazol group.

Keywords: hydroxamic acid, copper(II) complexes, mixed ligand complexes, histidine, glycine

\section{Introduction}

Hydroxamic acids having one or more $-\mathrm{CONHOH}$ groups have been extensively studied as a consequence of their biological importance which is related with their ability to form metal ion complexes. These acids are important also due to their pharmacological, toxicological and pathological properties ${ }^{1}$. Besides, they have a great number of applications in analytical chemistry ${ }^{2,3}$.
Monohydroxamic acids (such as acetohydroxamic acid, $\mathrm{CH}_{3} \mathrm{CONHOH}=$ Aha) after deprotonation acts as bidentate ligands forming octahedral complexes with a series of metal ions via co-ordination through the two oxygen atoms of the - $\mathrm{CONHO}^{-}$group. This type of co-ordination has been characterized in previous studies with $\mathrm{Fe}^{\mathrm{III}}, \mathrm{Cr}^{\mathrm{III}}, \mathrm{Ni}^{\mathrm{II}}, \mathrm{Co}^{\mathrm{II}}$, and $\mathrm{Zn}^{\mathrm{II}}$ ions, which indicated the formation of octahedral complexes both in the solid state and in solution ${ }^{4}$. With $\mathrm{Cu}^{\mathrm{II}}$ 
ions, the co-ordination again occurs via the two oxygen atoms but the geometry is tetragonal ${ }^{4}$.

Aminohydroxamic acids, due to the protonation of the amino group, have intricate acid base properties as shown by Farkas and Kiss ${ }^{5}$. Anions of $\alpha$-aminohydroxamic acids (such as glycinehydroxamic acid, $\mathrm{NH}_{2} \mathrm{CH}_{2} \mathrm{CON}$ $\mathrm{HOH}=\mathrm{Gha}$ ) are potentially able to form three kinds of a five member chelate complex using either: 1 - the two oxygens of the hydroxamate group, 2 - the two nitrogen atoms or, 3 - the nitrogen atom of the amino group and the oxygen of carbonyl group. As a result, they are powerful ligands for a great number of metal ions.

This work reports the results of a combined potentiometric and spectrophotometric study of $\mathrm{Cu}^{\mathrm{II}}$ mixed ligand complexes formed by one hydroxamic acid (Aha and Gha) taken as the primary ligand (A) and a secondary ligand $(\mathrm{B})$ represented either by histamine $(\mathrm{Ha})$ or by the aminoacids glycine (Gly) and histidine (His). All these ligands are potentially able to form chelate complexes with either five or six membered rings, displaying different co-ordination sites. Histamine has a N(amino) and a N(imidazol) donor groups, glycine has $\mathrm{N}$ (amino) and $\mathrm{O}$ (carboxylate) ones, while histidine has these three kinds of donor groups all together: one oxygen of the carboxylate group, one nitrogen of the imidazol group and the amino nitrogen atom. It may, therefore, act as a tridentate ligand while coordinating metal ions with octahedral geometry ${ }^{6}$. With the $\mathrm{Cu}^{\mathrm{II}}$ ion it is impossible to have the three donors atoms of histidine simultaneously occupying planar positions 6 . Two of these donor atoms will occupy equatorial positions, while the third one will either remain uncoordinated or occupy an axial position. The importance of the $\mathrm{Cu}^{\mathrm{II}}$ histidine co-ordination to explain the transport of copper in the human plasma has led to a series of investigations (involving potentiometry, spectroscopy in the UV, visible, infrared and Raman, calorimetry, X-ray and EPR) attempting to elucidate the structures of several $\mathrm{Cu}(\mathrm{II})$-histidine complexes which are formed in aqueous solutions. However a great deal of controversy still remains ${ }^{7-13}$.

The formation constant $(\log \beta)$ and the visible absorption spectrum were calculated for each one of the identified species, both binary and mixed ones. The most probable structures of the mixed species are discussed based upon their formation constants, their stabilization with regard to the two binary species and to their visible absorption spectra.

\section{Experimental}

\section{Reagents and Materials}

Histamine (dihydrocloride 99\%), glycinehydroxamic (90\%) and acetohydroxamic (95 to 98\%) acids were Sigma products. Glycine and histidine were Merck biochemical grade reagents. Solutions of these ligands were always prepared just before use with bidestilled water and their concentrations checked by direct potentiometric titrations.

A stock solution of copper(II) perchlorate was prepared from copper(II) nitrate and perchloric acid and its concentration determined by EDTA titration, using a copper ionselective electrode as an indicator ${ }^{14}$.

Sodium perchlorate solution, used to maintain constant the ionic strength at $0.1 \mathrm{~mol} / \mathrm{L}$, was prepared from sodium carbonate and perchloric acid. The concentration of this solution was determined by titrating the acid eluted after its treatment with a cationic resin (Dowex 50W-X8 Backer), loaded with $\mathrm{H}^{+}$ions, with $0.10 \mathrm{~mol} / \mathrm{L}$ carbonate free sodium hydroxide solution.

Carbonate free sodium hydroxide solutions were prepared with bidestilled water and standardized with potassium hydrogen phthalate.

All titrations were followed potentiometrically.

\section{General procedure}

To determine both the formation constant and the absorption spectrum of a given ternary or mixed species $\mathrm{M}_{\mathrm{p}} \mathrm{A}_{\mathrm{q}} \mathrm{B}_{\mathrm{r}} \mathrm{H}_{\mathrm{s}}$ (as define in expression 1) it is necessary to determine first the absorption spectra of the metal ion $\mathrm{M}$ and of both ligands A and B and of their protonated species, followed by the determination of the formation constant and the absorption spectrum of each binary species formed by $\mathrm{M}$ with both $\mathrm{A}$ and $\mathrm{B}$. Therefore, a series of steps are necessary which can be grouped as follows:

1 - Potentiometric titration of an acidified solution (with a strong mineral acid) of each ligand to determine the formation constant of each protonated species, under the same conditions which are being used (temperature, ionic strength, etc.), followed by a simultaneous potentiometric and spectrophotometric titration of the same solution to determine the absorption spectra of the free ligand and of each protonated species;

2 - Potentiometric titrations of solutions containg each ligand and copper(II) ion in several proportions, to determine the formation constants of each binary species $\mathrm{M}_{\mathrm{p}} \mathrm{A}_{\mathrm{q}} \mathrm{H}_{\mathrm{s}}$ and $\mathrm{M}_{\mathrm{p}} \mathrm{B}_{\mathrm{r}} \mathrm{H}_{\mathrm{s}}$, followed by simultaneous potentiometric and spectrophotometric titration of the same solutions to determine the absorption spectrum of each binary species $\mathrm{M}_{\mathrm{p}} \mathrm{A}_{\mathrm{q}} \mathrm{H}_{\mathrm{s}}$ and $\mathrm{M}_{\mathrm{p}} \mathrm{B}_{\mathrm{r}} \mathrm{H}_{\mathrm{s}}$;

3 - Potentiometric titrations of solutions containing two ligands and the ion copper(II) in different proportions to determine the formation constants of each ternary species $\mathrm{M}_{\mathrm{p}} \mathrm{A}_{\mathrm{q}} \mathrm{B}_{\mathrm{r}} \mathrm{H}_{\mathrm{s}}$, followed by simultaneous potentiometric and spectrophotometric titrations of the same solutions to determine the absorption spectrum of each ternary species $\mathrm{M}_{\mathrm{p}} \mathrm{A}_{\mathrm{q}} \mathrm{B}_{\mathrm{r}} \mathrm{H}_{\mathrm{s}}$.

\section{Potentiometric measurements}

The potentiometric titrations were performed by measuring the electromotive force ${ }^{15}$ (emf) of cells of the type (1) 
using as indicator the Metrohm glass electrode 6.0102.100(PB) and as reference the Metrohm calomel electrode 6.0702 .100 ( $\mathrm{NaCl} 0.1 \mathrm{~mol} / \mathrm{L}$ solution). The Titroprocessor Metrohm 670 was used to measure the electromotive force.

\begin{tabular}{l|c|c|c}
$\mathrm{Hg} / \mathrm{Hg}_{2} \mathrm{Cl}_{2}(\mathrm{~s})$ & $\mathrm{NaCl}(\mathrm{aq})$ & test solution & $\mathrm{Ev}$ (glass \\
$\begin{array}{l}\text { (reference } \\
\text { electrode) }\end{array}$ & $0.1 \mathrm{~mol} / \mathrm{L}$ & $\begin{array}{c}\left(\mathrm{NaClO}_{4}\right. \\
0.1 \mathrm{~mol} / \mathrm{L})\end{array}$ & electrode)
\end{tabular}

Solutions were added using a Metrohm Dosimat 665 autoburette, except the ligand solutions which were measured with a volumetric pipet. The ionic strength was adjusted to $0.10 \pm 0.01 \mathrm{~mol} / \mathrm{L}$ with a $\mathrm{NaClO}_{4}$ solution and the temperature was maintained constant inside the cell at 25.0 $\pm 0.1{ }^{\circ} \mathrm{C}$, by circulating thermostated water. The Metrohm 649 magnetic stirrer was used and all measurements were done under a nitrogen atmosphere. Standardized, carbonate free, sodium hydroxide solutions were used in all titrations.

The electrode system (1) was calibrated for hydrogen ion concentration ${ }^{12}$, before and after each series of measurements, by titration of perchloric acid (or sodium hydroxide) with standardized sodium hydroxide solution (or perchloric acid solution) at ionic strength of $0.10 \pm 0.01$ $\mathrm{mol} / \mathrm{L}$. Data were treated with a computer program ${ }^{16}$ which besides calculating the standard potential of electrode $\left(\mathrm{E}^{0}\right)$ gives also the calculated water dissociation constant $(\mathrm{Kw})$ under the experimental conditions which were being employed. These values were then used to calculate the hydrogen ion concentration $\left(\mathrm{pH}=-\log \left[\mathrm{H}^{+}\right]\right)$from measured potentials.

\section{Treatment of potentiometric data}

The equilibrium reactions in the systems which were investigated can be represented by the generic expression (charges omitted for simplification):

$$
\mathrm{pM}+\mathrm{qA}+\mathrm{rB}+\mathrm{sH} \rightleftharpoons \mathrm{M}_{\mathrm{p}} \mathrm{A}_{\mathrm{q}} \mathrm{B}_{\mathrm{r}} \mathrm{H}_{\mathrm{s}}
$$

The formation constant of the species $\mathrm{M}_{\mathrm{p}} \mathrm{A}_{\mathrm{q}} \mathrm{B}_{\mathrm{r}} \mathrm{H}_{\mathrm{s}}$ where $\mathrm{M}=\mathrm{Cu}^{\mathrm{II}}$ ion; $\mathrm{A}=$ ligand $\mathrm{A} ; \mathrm{B}=$ ligand $\mathrm{B} ; \mathrm{H}=$ proton and $\mathrm{p}, \mathrm{q}, \mathrm{r}$ and $\mathrm{s}$ represent their stoichiometric coefficients, is being defined as:

$$
\beta_{\mathrm{pqrs}}=\frac{\left[\mathrm{M}_{\mathrm{p}} \mathrm{A}_{\mathrm{q}} \mathrm{B}_{\mathrm{r}} \mathrm{H}_{\mathrm{s}}\right]}{[\mathrm{M}]^{\mathrm{p}}[\mathrm{A}]^{\mathrm{q}}[\mathrm{B}]^{\mathrm{r}}[\mathrm{H}]^{\mathrm{s}}}
$$

Tables 1 and 2 report details of the corresponding experimental conditions, i.e. the initial total concentrations of the reactants, number of titration points included and the $\mathrm{pH}$ ranges investigated. The electrode system being calibrated in the concentration scale, $\mathrm{pH}$ should be understood in terms of $-\log \left[\mathrm{H}^{+}\right]$throughout this study.

Formation constants were calculated using the computer program SUPERQUAD ${ }^{17}$ and are show in Tables 3 and 5. The standard deviations computed by this program (which refer to random errors only) is being used as an evidence of the presence of one species and of the adequacy of the equilibrium model tested.

\section{Spectrophotometric measurements}

The solutions while being potentiometrically titrated were continuously circulated, using a peristaltic pump, through a continuos flow quartz cuvette installed in a model 8451A Hewlett Packard spectrophotometer. This setup allowed simultaneous measurements of the volume of titrant $(\mathrm{NaOH})$ added, of the hydrogen ion concentration and of the absorbance of the solution. Titrations were performed with increments of volume and time intervals both prefixed (known as monotonous titration) in order to obtain an absorbance spectrum and the hydrogen ion concentration after each addition of the titrating solution. Spectrophotometric data were treated with the program SQUAD ${ }^{18}$.

The measured absorbance (A), in a given wavelength, at each point during the titration must take into account all the absorbing species, which includes the free $\mathrm{Cu}^{\mathrm{II}}$ ion, each free ligand and all its protonated derivatives as well as the various binary and mixed ligand $\mathrm{Cu}^{\mathrm{II}}$ complexes. If Beer's law is valid, then for each solution at any given wavelength, the absorbance $(\mathrm{A})$ is defined by the equation:

$$
\mathrm{A}=\sum_{\mathrm{p}} \sum_{\mathrm{q}} \sum_{\mathrm{r}} \sum_{\mathrm{s}} \varepsilon_{\mathrm{pqrs}} l \beta_{\mathrm{pqrs}}[\mathrm{M}]^{\mathrm{p}}[\mathrm{A}]^{\mathrm{q}}[\mathrm{B}]^{\mathrm{r}}[\mathrm{H}]^{\mathrm{s}}
$$

where: $\beta_{\mathrm{pqrs}}$ and $\varepsilon_{\mathrm{pqrs}}$ are the overall formation constant and the molar absorptivity at the given wavelength of the species $\mathrm{M}_{\mathrm{p}} \mathrm{A}_{\mathrm{q}} \mathrm{B}_{\mathrm{r}} \mathrm{H}_{\mathrm{s}}$, respectively, and $l$ is the pathlength of the cell used.

The values of $-\log [\mathrm{H}]$ were obtained from potentiometric measurements and since values of $\beta_{\text {pqrs }}$ had been already calculated by treating the potentiometric data, the values of $\varepsilon_{\text {pqrs }}$ could then be calculated. This was done stepwise. First, those of the free $\mathrm{Cu}^{\mathrm{II}}$ ion were determined separately. Since the measurements were made in the visible region of the spectra, $\varepsilon$ of the ligands were made equal to zero. Finaly, $\varepsilon$ of each one of the binary species were determined by titrating a mixture of $\mathrm{Cu}^{\mathrm{II}}$ ion with each of the ligands separately.

Once the binary complexes formation constants were determined, solutions containing two ligands in the presence of copper(II) were titrated first potentiometrically and then spectrophotometrically. There was always an excess of ligand with respect to the metal ion and more than one ratio between the two ligands was used.

Table 4 reports the essentials of the corresponding experimental conditions: the initial total concentrations and the $\mathrm{pH}$ ranges investigated. The data treated in each case involved a total of 100 wavelengths (from 400 to $800 \mathrm{~nm}$ ) and a significant number of spectra, as shown in this table. The spectrophotometric data are show in Table 5. 
Table 1. Summary of the potentiometric titration data used in the formation constants calculation. Initial total concentrations of $\mathrm{Cu}^{\mathrm{II}}\left(\mathrm{CM}_{\mathrm{M}}\right)$, ligand $\mathrm{A}\left(\mathrm{C}_{\mathrm{A}}\right)$, mineral acid $\left(\mathrm{C}_{\mathrm{H}}\right)$. Number of titration points $(\mathrm{NP})$ and $-\log \left[\mathrm{H}^{+}\right]$range included. Concentrations are expressed in $\mathrm{mmol} / \mathrm{L}$.

\begin{tabular}{|c|c|c|c|c|c|}
\hline System & $\mathrm{C}_{\mathrm{M}}$ & $\mathrm{C}_{\mathrm{A}}$ & $\mathrm{C}_{\mathrm{H}}$ & $\mathrm{NP}$ & $\mathrm{pH}$ range \\
\hline \multirow[t]{7}{*}{ Proton-Aha } & & 17.96 & 17.88 & 54 & $6.99-10.96$ \\
\hline & & 18.05 & 18.00 & 54 & $6.88-10.70$ \\
\hline & & 19.68 & 19.68 & 33 & $6.40-10.93$ \\
\hline & & 19.68 & 19.67 & 33 & $6.56-10.98$ \\
\hline & & 19.60 & 19.60 & 28 & $6.53-9.95$ \\
\hline & & 19.52 & 19.50 & 31 & $6.64-10.76$ \\
\hline & & 19.52 & 19.55 & 31 & $6.44-10.72$ \\
\hline \multirow[t]{2}{*}{ Copper-Aha } & 2.00 & 19.68 & 19.68 & 36 & $3.02-7.65$ \\
\hline & 3.00 & 19.68 & 19.68 & 35 & $2.92-8.04$ \\
\hline \multirow[t]{4}{*}{ Proton-Gha } & & 8.54 & 18.59 & 150 & $2.80-10.30$ \\
\hline & & 9.38 & 19.17 & 36 & $3.40-9.90$ \\
\hline & & 9.38 & 19.28 & 36 & $3.24-9.72$ \\
\hline & & 10.15 & 22.54 & 51 & $2.57-10.89$ \\
\hline \multirow[t]{4}{*}{ Copper-Gha } & 1.84 & 8.54 & 18.59 & 79 & $2.82-10.16$ \\
\hline & 2.76 & 8.54 & 18.59 & 79 & $2.80-10.04$ \\
\hline & 3.68 & 8.54 & 18.59 & 80 & $2.79-10.05$ \\
\hline & 4.60 & 8.54 & 18.59 & 82 & $2.80-10.04$ \\
\hline \multirow[t]{2}{*}{ Proton-Gly } & & 10.12 & 21.63 & 48 & $2.22-11.09$ \\
\hline & & 10.12 & 21.74 & 48 & $2.23-11.05$ \\
\hline \multirow[t]{2}{*}{ Copper-Gly } & 2.00 & 10.12 & 10.12 & 30 & $3.45-.6 .74$ \\
\hline & 3.00 & 10.12 & 10.12 & 36 & $3.32-7.99$ \\
\hline \multirow[t]{5}{*}{ Proton-Ha } & & 9.76 & 19.52 & 45 & $4.14-10.74$ \\
\hline & & 9.72 & 19.44 & 45 & $4.20-10.80$ \\
\hline & & 9.96 & 19.92 & 88 & $4.16-10.72$ \\
\hline & & 9.88 & 19.72 & 92 & $4.15-10.98$ \\
\hline & & 9.80 & 19.60 & 97 & $4.18-11.02$ \\
\hline \multirow[t]{6}{*}{ Copper-Ha } & 2.50 & 9.76 & 19.51 & 33 & $3.55-8.06$ \\
\hline & 2.50 & 9.76 & 19.51 & 17 & $3.83-7.34$ \\
\hline & 2.00 & 9.76 & 19.52 & 34 & $3.59-8.23$ \\
\hline & 2.00 & 9.76 & 19.08 & 32 & $3.89-8.37$ \\
\hline & 2.00 & 10.00 & 19.97 & 32 & $3.58-8.27$ \\
\hline & 2.00 & 10.00 & 20.01 & 32 & $3.77-7.99$ \\
\hline \multirow[t]{4}{*}{ Proton-His } & & 6.79 & 47.42 & 60 & $1.53-10.87$ \\
\hline & & 6.85 & 47.69 & 56 & $1.54-10.25$ \\
\hline & & 6.64 & 47.18 & 57 & $1.55-10.56$ \\
\hline & & 6.72 & 47.42 & 56 & $1.55-10.28$ \\
\hline \multirow[t]{3}{*}{ Copper-His } & 1.84 & 8.96 & 17.88 & 74 & $3.07-10.23$ \\
\hline & 2.76 & 8.96 & 17.88 & 71 & $2.97-10.02$ \\
\hline & 3.68 & 8.96 & 17.88 & 72 & $2.90-9.87$ \\
\hline
\end{tabular}


Table 2. Summary of the potentiometric titration data used in the formation constants calculation. Initial total concentrations of $\mathrm{Cu}^{\mathrm{II}}\left(\mathrm{C}_{\mathrm{M}}\right)$, ligand $\mathrm{A}\left(\mathrm{C}_{\mathrm{A}}\right)$, ligand $\mathrm{B}\left(\mathrm{CB}_{\mathrm{B}}\right)$, mineral acid $\left(\mathrm{C}_{\mathrm{H}}\right)$. Number of titration points $(\mathrm{NP})$ and $-\log \left[\mathrm{H}^{+}\right]$range included. Concentrations are expressed in $\mathrm{mmol} / \mathrm{L}$.

\begin{tabular}{|c|c|c|c|c|c|c|}
\hline System & $\mathrm{C}_{\mathrm{M}}$ & $\mathrm{C}_{\mathrm{A}}$ & $\mathrm{C}_{\mathrm{B}}$ & $\mathrm{C}_{\mathrm{H}}$ & NP & $\mathrm{pH}$ range \\
\hline \multirow[t]{5}{*}{ Copper-Aha-Gly } & 1.00 & 9.80 & 5.06 & 14.80 & 19 & $3.51-7.20$ \\
\hline & 2.00 & 9.80 & 5.06 & 14.86 & 22 & $3.27-7.18$ \\
\hline & 2.00 & 5.88 & 10.12 & 15.95 & 21 & $3.37-7.10$ \\
\hline & 3.00 & 9.80 & 5.06 & 14.91 & 24 & $3.15-7.13$ \\
\hline & 3.00 & 9.80 & 5.06 & 14.77 & 28 & $3.20-7.44$ \\
\hline \multirow[t]{6}{*}{ Copper-Aha-Ha } & 1.00 & 9.76 & 4.94 & 19.65 & 18 & $3.31-6.01$ \\
\hline & 2.00 & 9.76 & 9.88 & 29.62 & 22 & $3.15-6.05$ \\
\hline & 2.00 & 5.86 & 9.88 & 25.69 & 21 & $3.21-6.02$ \\
\hline & 3.00 & 9.76 & 4.94 & 19.71 & 22 & $3.03-6.00$ \\
\hline & 2.00 & 5.98 & 9.80 & 25.84 & 29 & $3.33-6.07$ \\
\hline & 3.00 & 9.96 & 4.90 & 19.88 & 55 & $3.06-6.09$ \\
\hline \multirow[t]{5}{*}{ Copper-Aha-His } & 2.76 & 9.02 & 4.60 & 17.95 & 82 & $2.97-10.86$ \\
\hline & 3.68 & 9.02 & 4.60 & 17.95 & 84 & $2.90-10.83$ \\
\hline & 4.60 & 9.02 & 4.60 & 17.98 & 83 & $2.84-10.87$ \\
\hline & 3.00 & 10.00 & 5.08 & 20.24 & 59 & $2.96-10.32$ \\
\hline & 4.00 & 10.00 & 5.08 & 20.36 & 33 & $2.95-10.62$ \\
\hline \multirow[t]{4}{*}{ Copper-Gha-Gly } & 4.00 & 5.20 & 10.48 & 22.19 & 34 & $3.06-8.07$ \\
\hline & 4.00 & 4.16 & 10.48 & 19.76 & 33 & $3.08-8.17$ \\
\hline & 5.00 & 5.20 & 10.48 & 22.11 & 35 & $3.02-8.00$ \\
\hline & 4.00 & 3.14 & 10.48 & 17.53 & 29 & $3.14-6.57$ \\
\hline \multirow[t]{5}{*}{ Copper-Gha-Ha } & 4.00 & 5.16 & 9.88 & 31.18 & 77 & $3.06-10.56$ \\
\hline & 4.00 & 4.13 & 9.88 & 29.12 & 72 & $3.17-10.52$ \\
\hline & 5.25 & 6.25 & 6.23 & 26.42 & 52 & $2.80-10.49$ \\
\hline & 4.20 & 6.25 & 12.45 & 38.66 & 56 & $2.81-10.60$ \\
\hline & 4.20 & 5.00 & 12.45 & 35.87 & 54 & $2.90-10.48$ \\
\hline \multirow[t]{4}{*}{ Copper-Gha-His } & 0.92 & 4.25 & 4.50 & 18.13 & 72 & $3.06-10.07$ \\
\hline & 1.84 & 4.25 & 4.50 & 18.05 & 74 & $2.98-10.02$ \\
\hline & 2.76 & 4.25 & 4.50 & 18.00 & 74 & $2.91-10.03$ \\
\hline & 3.68 & 4.25 & 4.50 & 17.99 & 75 & $2.86-10.07$ \\
\hline
\end{tabular}

\section{Results and Discussion}

\section{Binary systems}

Ligand protonation constants were potentiometrically redetermined by titrating acidified $2.5 \times 10^{-2} \mathrm{~mol} / \mathrm{L}$ solutions of the ligands with $0.1 \mathrm{~mol} / \mathrm{L} \mathrm{NaOH}$ solution. The results, shown in Table 3, are in good agreement with previously reported values ${ }^{4,19}$.

Binary complexes formation constants were also redetermined potentiometrically from titration data of solutions containing the ligands in the presence of copper(II), using always an excess of ligand and more than one ligand to metal ratio. The results, also shown in Table 3, are in agreement with literature values ${ }^{4,19}$. Treatment of the spec- trophotometric data by SQUAD also allowed the calculation of the visible absorption spectrum of all the species which are formed in these systems, as shown in Figs. 1-5.

Bidentate ligand co-ordination in these complex species is either already known or foreseeable ${ }^{6}$.

$\mathrm{Cu}^{\mathrm{II}}$-acetohydroxamic acid: the anion of this acid $(\mathrm{pKa}=9.230)$ co-ordinates through the two oxygen atoms of the hydroxamate group. Hence, spectra 1 and 2 of Fig. 1 are characteristic of an aqueous solution of $\mathrm{Cu}^{\mathrm{II}}$ ions bound to one $\left([\mathrm{Cu}(\mathrm{Aha})]^{+}, \lambda_{\max }=760 \mathrm{~nm}\right)$ and two hydroxamate groups $\left(\left[\mathrm{Cu}(\mathrm{Aha})_{2}\right], \lambda_{\max }=660 \mathrm{~nm}\right)$, respectively.

$\mathrm{Cu}^{\text {II }}$-glycinehydroxamic acid: this water insoluble acid can be dissolved either in acidic or basic solutions, as a result of protonation of the amino group $(\mathrm{pKa}=7.615)$ or 
Table 3. Overall protonation and complex formation constants $(\log \beta)$ of the binary systems, $25{ }^{\circ} \mathrm{C}, \mathrm{I}=0.1 \mathrm{~mol} / \mathrm{L}\left(\mathrm{NaClO}_{4}\right)$.

\begin{tabular}{lccccc}
\hline SPECIES/LIGAND & $\mathrm{Aha}^{-}$ & $\mathrm{Gha}^{-}$ & $\mathrm{Gly}^{-}$ & Ha & $\mathrm{His}^{-}$ \\
\hline$[\mathrm{HL}]$ & $9.230(4)$ & $9.16(1)$ & $9.516(7)$ & $9.743(7)$ & $9.048(5)$ \\
{$\left[\mathrm{H}_{2} \mathrm{~L}\right]$} & - & $16.572(1)$ & $11.818(9)$ & $15.788(8)$ & $15.13(2)$ \\
{$\left[\mathrm{H}_{3} \mathrm{~L}\right]$} & - & - & - & - & $17.06(9)$ \\
{$[\mathrm{CuLH}]$} & - & - & - & - & $14.331(6)$ \\
{$[\mathrm{CuL}]$} & $7.867(5)$ & $10.78(3)$ & $8.093(5)$ & $9.459(6)$ & $10.452(9)$ \\
{$\left[\mathrm{CuL}_{2} \mathrm{H}\right]$} & - & - & - & $21.31(2)$ & $23.968(7)$ \\
{$\left[\mathrm{CuL}_{2}\right]$} & $14.004(8)$ & $19.95(1)$ & $14.960(7)$ & $15.97(1)$ & $18.220(7)$ \\
{$\left[\mathrm{CuL}_{2} \mathrm{OH}\right]$} & & $10.10(2)$ & - & - & $7.54(3)$ \\
{$\left[\mathrm{Cu}_{2} \mathrm{~L}_{2} \mathrm{OH}\right]$} & - & $20.98(1)$ & - & - & \\
\hline
\end{tabular}

* Numbers in parenthesis are the standard deviation.

Table 4. Summary of the spectrophotometric titration data used in the molar absortivities calculation. Initial total concentrations of $\mathrm{Cu}^{\mathrm{II}}\left(\mathrm{C}_{\mathrm{M}}\right)$, ligand $\mathrm{A}$ $\left(\mathrm{C}_{\mathrm{A}}\right)$, ligand $\mathrm{B}\left(\mathrm{CB}_{\mathrm{B}}\right)$. Number of spectra $(\mathrm{NS})$ and $-\log \left[\mathrm{H}^{+}\right]$range included. Concentrations are expressed in $\mathrm{mmol} / \mathrm{L}$.

\begin{tabular}{|c|c|c|c|c|c|}
\hline System & $\mathrm{C}_{\mathrm{M}}$ & $\mathrm{C}_{\mathrm{A}}$ & $\mathrm{C}_{\mathrm{B}}$ & NS & $\mathrm{pH}$ range \\
\hline \multicolumn{6}{|l|}{ Copper-Aha } \\
\hline & 2.00 & 19.68 & - & 10 & $3.16-7.50$ \\
\hline & 3.00 & 19.68 & - & 8 & $3.12-8.04$ \\
\hline \multicolumn{6}{|l|}{ Copper-Gha } \\
\hline & 1.84 & 9.40 & - & 30 & $3.16-11.03$ \\
\hline & 2.76 & 9.40 & - & 29 & $3.23-10.67$ \\
\hline & 3.68 & 9.40 & - & 31 & $3.31-10.33$ \\
\hline \multicolumn{6}{|l|}{ Copper-Gly } \\
\hline & 2.00 & - & 10.12 & 14 & $3.41-7.99$ \\
\hline & 3.00 & - & 10.12 & 10 & $3.57-8.29$ \\
\hline \multirow[t]{2}{*}{ Copper-Ha } & 2.00 & - & 10.00 & 32 & $3.77-7.99$ \\
\hline & 2.50 & - & 9.76 & 17 & $3.83-7.34$ \\
\hline \multirow[t]{2}{*}{ Copper-His } & 2.00 & - & 9.96 & 46 & $2.98-10.51$ \\
\hline & 4.00 & - & 9.96 & 26 & $3.19-11.01$ \\
\hline Copper-Aha-Gly & 3.00 & 9.80 & 5.06 & 28 & $3.20-7.44$ \\
\hline \multirow[t]{2}{*}{ Copper-Aha-Ha } & 2.00 & 5.98 & 9.80 & 29 & $3.33-6.07$ \\
\hline & 3.00 & 9.96 & 4.90 & 54 & $3.06-6.09$ \\
\hline \multirow[t]{2}{*}{ Copper-Aha-His } & 3.00 & 10.10 & 5.08 & 59 & $2.96-10.32$ \\
\hline & 4.00 & 10.10 & 5.08 & 31 & $2.95-10.33$ \\
\hline Copper-Gha-Gly & 4.00 & 4.06 & 10.12 & 31 & $3.13-8.03$ \\
\hline Copper-Gha-Ha & 4.00 & 9.88 & 5.16 & 83 & $3.52-11.22$ \\
\hline \multirow[t]{2}{*}{ Copper-Gha-His } & 2.00 & 5.20 & 5.08 & 30 & $3.11-9.71$ \\
\hline & 4.00 & 5.20 & 5.08 & 59 & $2.89-9.45$ \\
\hline
\end{tabular}


Table 5. Overall formation constants $(\log \beta)$, stepwise formation constants $\left(\log \mathrm{K}_{\mathrm{ad}}\right)$ stabilization parameter $(\log X)$, maximum wavelength (nm) and molar absortivity $(\mathrm{L} / \mathrm{mol} \mathrm{cm})$ of mixed ligand species.

\begin{tabular}{|c|c|c|c|c|c|}
\hline Species & $\log \beta$ & $\log K_{a d}$ & $\log X$ & $\lambda_{\max }$ & $\varepsilon$ \\
\hline [Cu(Aha)(Gly)] & $14.97(1)$ & 7.10 & 0.98 & 652 & 34 \\
\hline$[\mathrm{Cu}(\mathrm{Aha})(\mathrm{Ha})]^{+}$ & $17.31(1)$ & 9.44 & 4.65 & 624 & 50 \\
\hline$[\mathrm{Cu}(\mathrm{Aha})(\mathrm{His})]$ & $17.804(8)$ & 9.94 & 3.38 & 624 & 44 \\
\hline$[\mathrm{Cu}(\mathrm{Aha})(\mathrm{His}) \mathrm{OH}]^{-}$ & $7.55(1)$ & - & - & 584 & 66 \\
\hline [Cu(Gha)(Gly)] & $18.07(3)$ & 7.29 & 1.23 & 596 & 63 \\
\hline$[\mathrm{Cu}(\mathrm{Gha})(\mathrm{Ha})]^{+}$ & $19.34(2)$ & 8.56 & 2.76 & 564 & 75 \\
\hline$[\mathrm{Cu}(\mathrm{Gha})(\mathrm{Ha}) \mathrm{OH}]$ & $8.89(5)$ & - & - & 564 & 74 \\
\hline$[\mathrm{Cu}(\mathrm{Gha})(\mathrm{His}) \mathrm{H}]^{+}$ & $25.04(3)$ & - & - & 612 & 48 \\
\hline$[\mathrm{Cu}(\mathrm{Gha})(\mathrm{His})]$ & $20.00(2)$ & 9.22 & 1.83 & 572 & 75 \\
\hline$[\mathrm{Cu}(\mathrm{Gha})(\mathrm{His}) \mathrm{OH}]^{-}$ & $10.11(4)$ & - & - & 564 & 48 \\
\hline
\end{tabular}

* Numbers in parenthesis are the standard deviation.

deprotonation of the hydroxamic acid group $(\mathrm{pKa}=9.159)$. Even though it is the $\mathrm{OH}$ of the $\mathrm{CONHOH}$ group that deprotonates, the glicinehydroxamate anion ( $\left.\mathrm{Gha}^{-}\right)$co-ordinates to $\mathrm{Cu}^{\mathrm{II}}$ ions via the two nitrogen atoms, from the amino and the hydroxamate groups $^{20 \mathrm{a}, 20 \mathrm{~b}}$. Spectra 1 $\left([\mathrm{Cu}(\mathrm{Gha})]^{+}, \lambda_{\max }=684 \mathrm{~nm}\right)$ and $2\left(\left[\mathrm{Cu}(\mathrm{Gha})_{2}\right], \lambda_{\max }=540\right.$ $\mathrm{nm}$ ) of Fig. 2 are therefore characteristic of aqueous $\mathrm{Cu}^{\mathrm{II}}$ bound to one and two such groups. Deprotonation of $\left[\mathrm{Cu}(\mathrm{Gha})_{2}\right](\mathrm{pKa}=9.85)$ giving the species $\left[\mathrm{Cu}(\mathrm{Gha})_{2} \mathrm{OH}\right]^{-}$ is the result of the hydroxamate group loosing one more proton as has been already shown by X-ray analysis for a $\mathrm{Ni}$ (II) analogue complex ${ }^{20 c}$. Spectrum 3 of this figure shows a resulting shift in $\lambda_{\max }$ from 540 to $504 \mathrm{~nm}$. For the dimeric species $\left[\mathrm{Cu}_{2}(\mathrm{Gha})_{2} \mathrm{OH}\right]^{+},\left(\lambda_{\max }=644 \mathrm{~nm}\right.$ as shown by spectrum 4 of this figure) we have proposed ${ }^{20 a}$ one $\mathrm{OH}$ bridging two $\mathrm{Cu}-\mathrm{Gha}$ units, a hypothesis which is contested by Farkas and $\mathrm{col}^{5}$.

$\mathrm{Cu}^{\text {II }}$-glycine: the glycinate anion co-ordinates via the amino $(\mathrm{pKa}=9.516)$ and the carboxylate groups $(\mathrm{pKa}=$ 2.302). Therefore, spectra 1 and 2 of Fig. 3 shows the spectra of $\mathrm{Cu}^{\mathrm{II}}$ bound to one $\left([\mathrm{Cu}(\mathrm{Gly})]^{+}, \lambda_{\max }=732 \mathrm{~nm}\right)$ and two glycinate groups $\left(\left[\mathrm{Cu}(\mathrm{Gly})_{2}\right], \lambda_{\max }=624 \mathrm{~nm}\right)$, respectively.

Cu'-histamine: The crystal structure of $\left[\mathrm{Cu}(\mathrm{Ha})_{2}\right]\left(\mathrm{ClO}_{4}\right)_{2}$ has been determined and no unusual features were found, the nitrogen atoms from two planar imidazol rings occupy trans co-ordination positions ${ }^{21}$. But histamine may also act as a monodentade ligand in which case the imidazol group remains protonated as well as a bidentate one when coordinating via the nitrogen atoms of the amino and imidazol groups. Therefore, spectra 1 and 2 of Fig. 4 shows $\mathrm{Cu}^{\mathrm{II}}$ bound to one $\left([\mathrm{Cu}(\mathrm{Ha})]^{2+} ; \lambda_{\max }=680\right.$ $\mathrm{nm})$ and two bidentate histamine molecules $\left(\left[\mathrm{Cu}(\mathrm{Ha})_{2}\right]^{2+}\right.$; $\lambda_{\max }=596 \mathrm{~nm}$ ), while spectrum 3 of this figure shows $\mathrm{Cu}^{\mathrm{II}}$, as $\left[\mathrm{Cu}(\mathrm{Ha})_{2} \mathrm{H}\right]^{3+}\left(\lambda_{\max }=624 \mathrm{~nm}\right)$, bound simultaneously to a bidentate and a monodentate histamine molecule.

Cu ${ }^{\text {II }}$-histidine: In histidine, the carboxylate group $\left(\mathrm{pK}_{\mathrm{a}}\right.$ $=1.93)$, the imidazol nitrogen $\left(\mathrm{pK}_{\mathrm{a}}=6.08\right)$ and the amino nitrogen $\left(\mathrm{pK}_{\mathrm{a}}=9.05\right)$ become available for co-ordination as the $\mathrm{pH}$ increases, as shown by the Scheme $1^{7}$.

Results of X-ray studies have shown that histidine can use each one of the three possible co-ordination sites for bonding to metal ions ${ }^{10}$. Bidentate chelation using either an imidazol-amino or an amino-carboxylate co-ordination pair are feasible. The possibility of imidazol-carboxylate bidentate co-ordination is disfavoured by the seven member ring involved.

There has been controversy regarding the solution structure of $[\mathrm{Cu}(\mathrm{His}) \mathrm{H}]^{2+}$. Coordination of both the amino and imidazol groups is popular ${ }^{7}$, but a glycine-like coordination has also been proposed ${ }^{22}$. This structure seems to us the most probable since there is close similarity between the spectrum of this species, shown in Fig. $5\left(\lambda_{\max }=716\right.$ $\mathrm{nm})$, and the one of $[\mathrm{Cu}(\mathrm{Gly})]^{+}\left(\lambda_{\max }=732 \mathrm{~nm}\right)$. Therefore there is co-ordination in this complex of the amino and of the carboxylate groups to the $\mathrm{Cu}^{\mathrm{II}}$ ion, the imidazol group

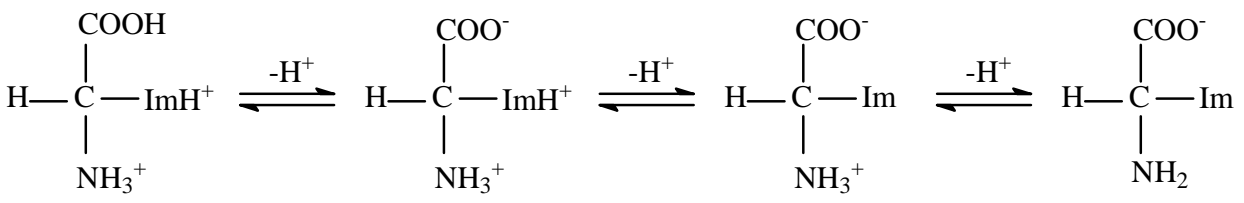

Scheme 1. 


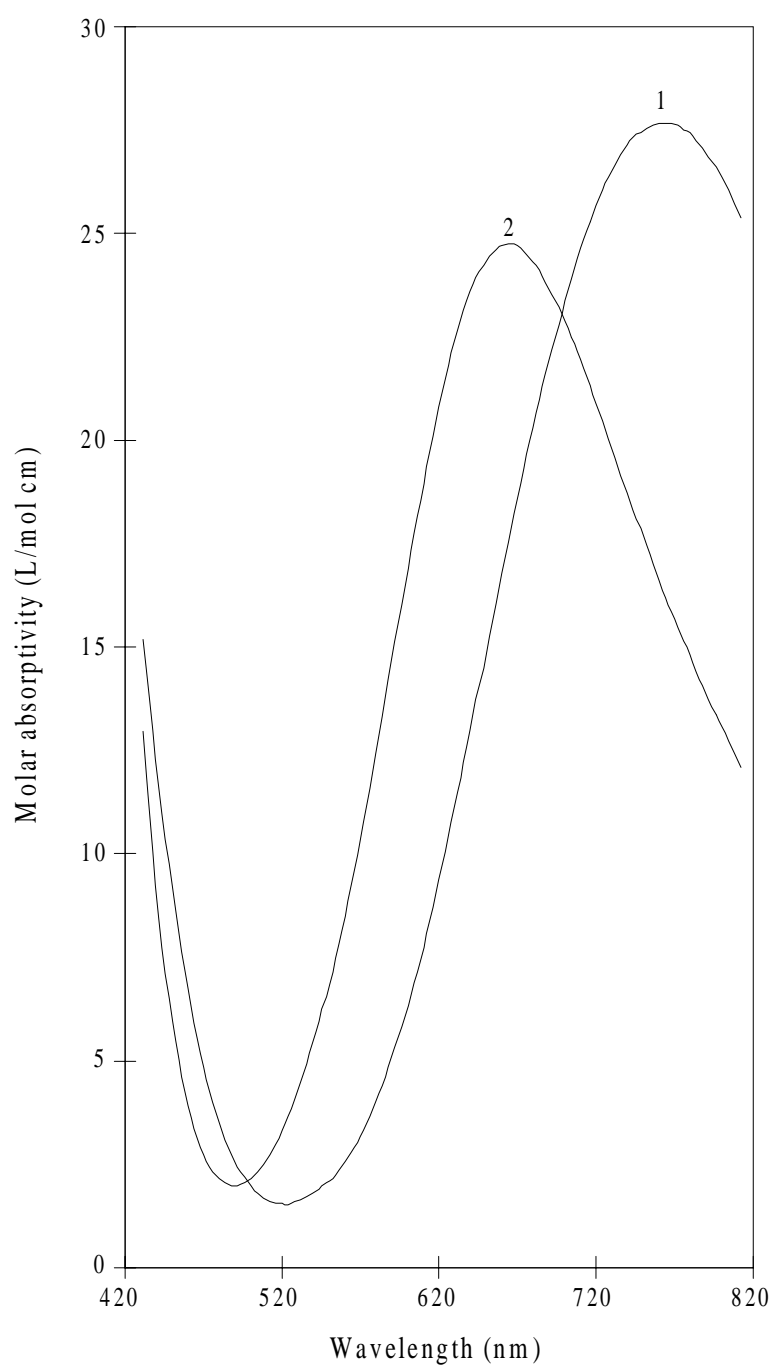

Figure 1. Calculated molar absorptivities of $\mathrm{Cu}(\mathrm{II})$-acetohydroxamic acid complexes. 1- $[\mathrm{Cu}(\mathrm{Aha})]^{+}, 2-[\mathrm{Cu}(\mathrm{Aha}) 2]$.

remaining protonated, as shown in Structure 1. This is the same type of co-ordination observed in crystals of $\left[\mathrm{Cu}(\mathrm{HisH})_{2}\right]^{2+}$, as shown by $\mathrm{X}$ ray analysis ${ }^{23}$.

The absorption spectrum of $[\mathrm{Cu}(\mathrm{His})]^{+}\left(\lambda_{\max }=664 \mathrm{~nm}\right)$ resembles that of $[\mathrm{Cu}(\mathrm{Ha})]^{2+}\left(\lambda_{\max }=680 \mathrm{~nm}\right)$ and it is generally agreed that in this species, histidinate bonding to the $\mathrm{Cu}^{\mathrm{II}}$ ion occurs via two nitrogen donor atoms in the co-ordination plane, with an axial carboxylate weakly coordinated or uncoordinated, as shown in Structure 2.
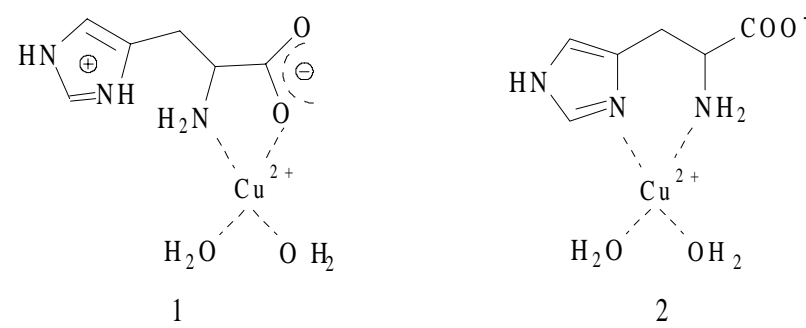

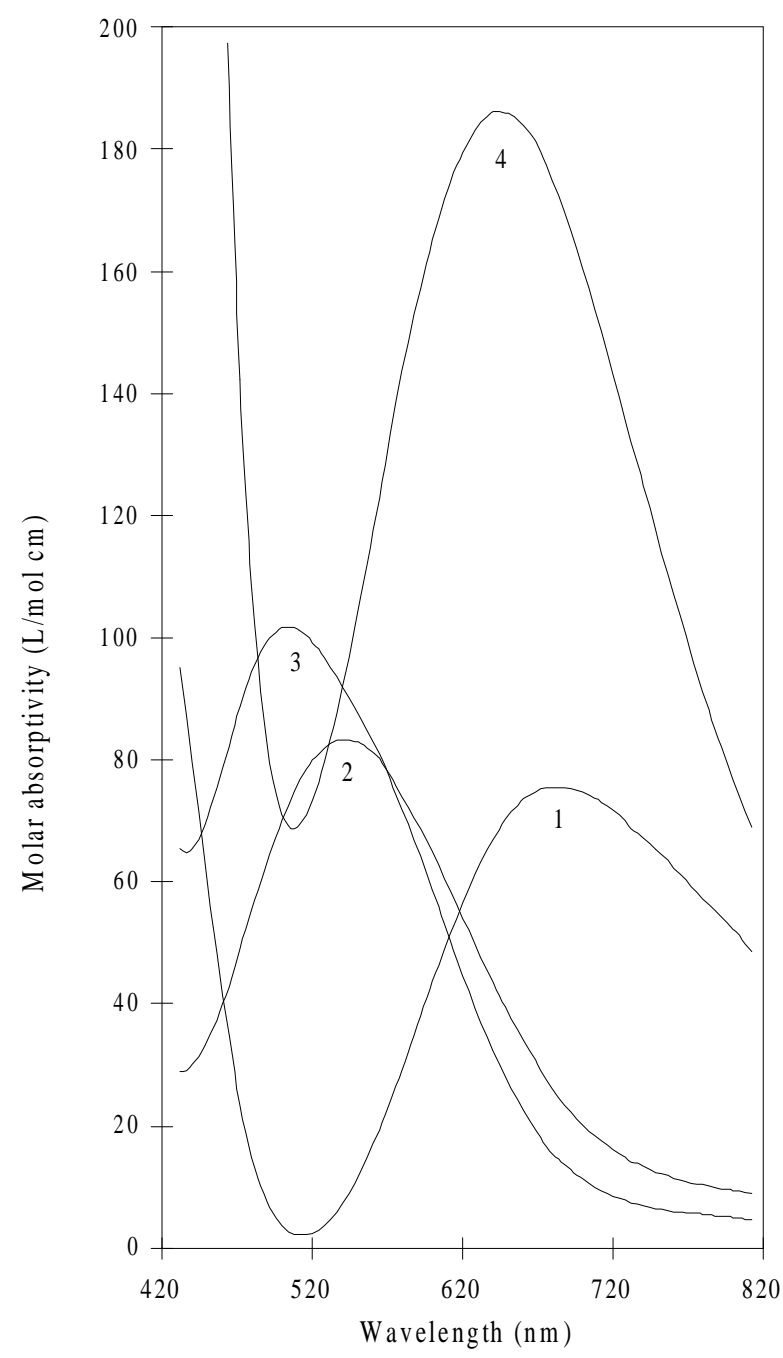

Figure 2. Calculated molar absorptivities of $\mathrm{Cu}(\mathrm{II})$-glycinehydroxamic acid complexes. 1- $[\mathrm{Cu}(\mathrm{Gha})]^{+}, 2-\left[\mathrm{Cu}(\mathrm{Gha})_{2}\right], 3-\left[\mathrm{Cu}(\mathrm{Gha})_{2} \mathrm{OH}\right]^{-}, 4-$ $\left[\mathrm{Cu}_{2}(\mathrm{Gha})_{2} \mathrm{OH}\right]^{+}$.

It has been suggested ${ }^{7}$ that in $\left[\mathrm{Cu}(\mathrm{His})_{2} \mathrm{H}\right]^{+}\left(\lambda_{\max }=608\right.$ $\mathrm{nm}$ ) co-ordination occurs through a combination of the ones occurring in both [CuHis $]^{+}$and $[\mathrm{CuHisH}]^{2+}$. However Structure 3 , which has already been suggested ${ }^{24}$, seems the most probable, considering the close similarity between its spectrum and the one of $\left[\mathrm{Cu}(\mathrm{Ha})_{2}\right]^{2+}$.

Several propositions have been made for the structure of the species $\left[\mathrm{Cu}(\mathrm{His})_{2}\right]\left(\lambda_{\max }=640 \mathrm{~nm}\right)$. Attempts to isolate $\left[\mathrm{Cu}(\mathrm{l}-\mathrm{His})_{2}\right]$ in neutral $\mathrm{pH}$ were unsuccessful. Camerman ${ }^{17}$ has succeeded in crystallizing $[\mathrm{Cu}(\mathrm{l}-\mathrm{His})(\mathrm{d}$ His)] and has shown that, in the solid state, co-ordination occurs via the nitrogen atoms of the amino and imidazol groups. Two water molecule are co-ordinated to the $\mathrm{Cu}(\mathrm{II})$ axial positions and they are H-bonded to carboxylate groups of each histidine molecule. Considering the shift in the spectrum of $608 \mathrm{~nm}$ of the protonated species to $640 \mathrm{in}$ this neutral one, it does not seem reasonable to propose that 


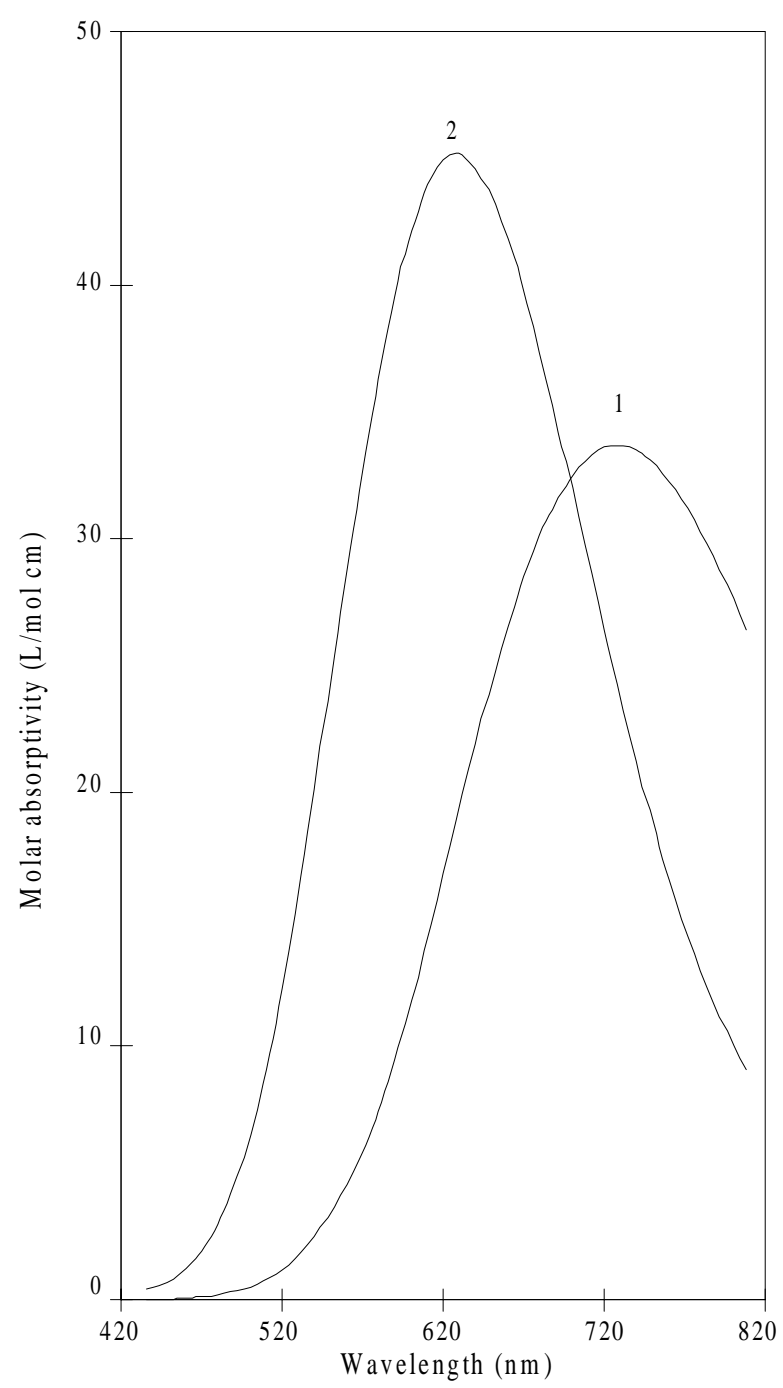

Figure 3. Calculated molar absorptivities of $\mathrm{Cu}(\mathrm{II})$-glycine complexes. 1- $[\mathrm{Cu}(\mathrm{Gly})]^{+}, 2-\left[\mathrm{Cu}(\mathrm{Gly})_{2}\right]$.

this arrangement remains in solution. Actually, arguments have already been presented by Sigel and McCormick, considering this species to consist of two histidine anions with trans amino groups, the tetragonal plane consisting of a substituted glicinate from one histidine and two nitrogens from the other, as shown in Structure 4. This structure would be dynamic with Jahn-Teller distortions carrying

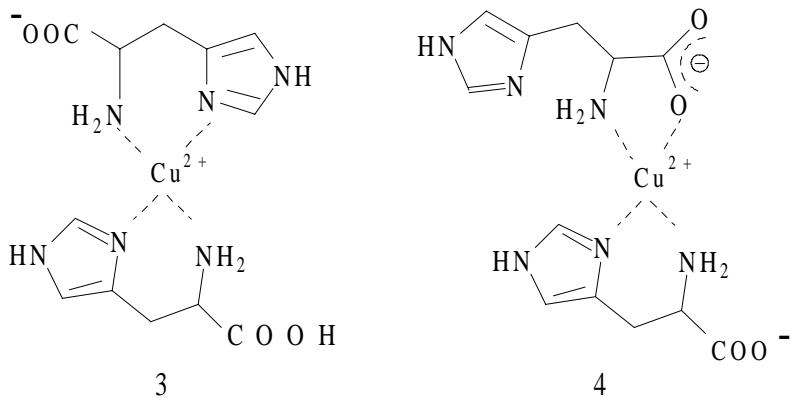

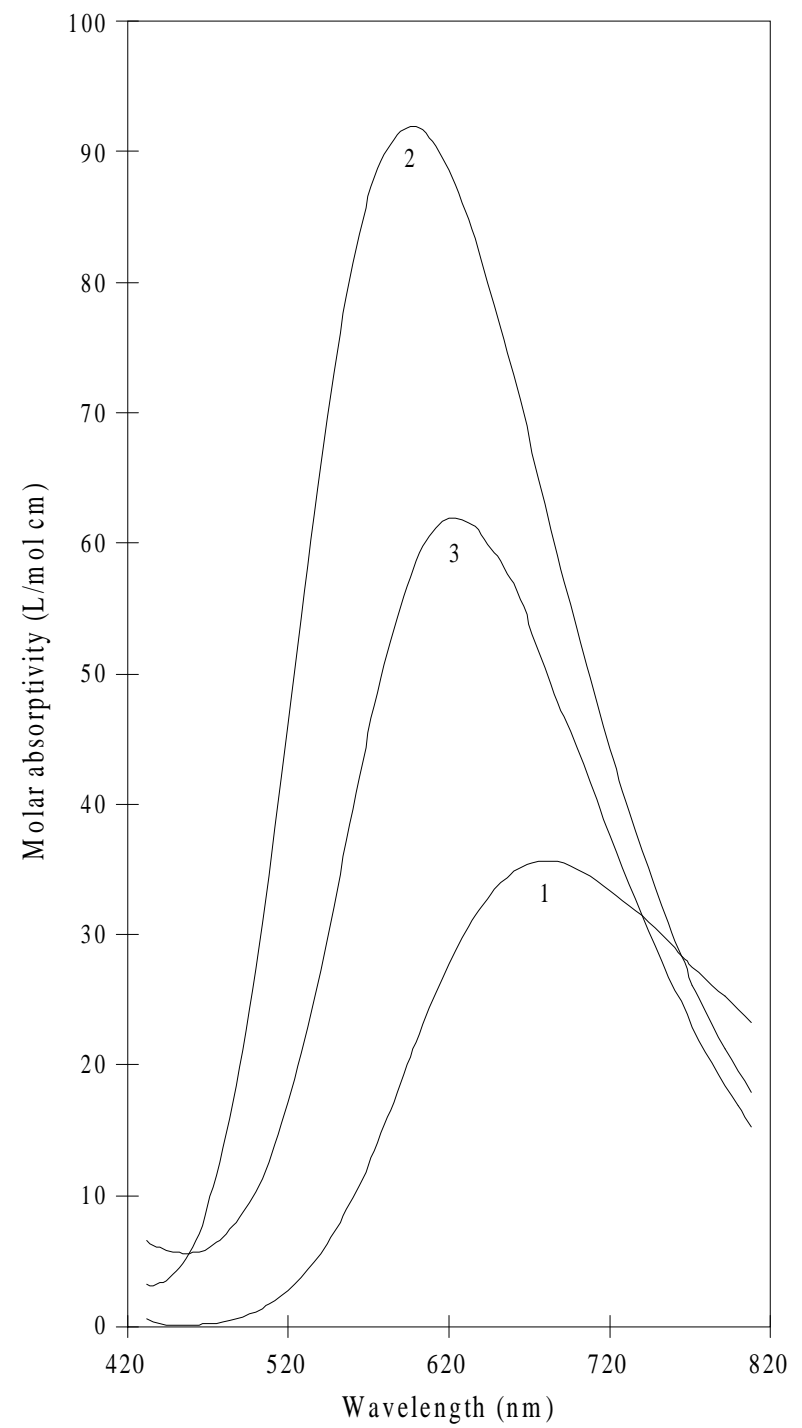

Figure 4. Calculated molar absorptivities of $\mathrm{Cu}$ (II)-histamine complexes. 1- $[\mathrm{Cu}(\mathrm{Ha})]^{2+}, 2-\left[\mathrm{Cu}(\mathrm{Ha})_{2}\right]^{2+}, 3-\left[\mathrm{Cu}(\mathrm{Ha})_{2} \mathrm{H}\right]^{3+}$.

first one set of trans imidazol-carboxylate groups into an axial position and then the other ${ }^{25}$.

Finally, for the species $\left[\mathrm{Cu}(\mathrm{His})_{2} \mathrm{OH}\right]^{-}\left(\lambda_{\max }=636 \mathrm{~nm}\right)$, the most probable structure results simply from a loss of a proton from one of the imidazol groups shown in Structure 4.

\section{Mixed ligand systems}

A parameter, known as $\log \mathrm{X}$, is frequently used to characterise the stability of ternary or mixed complexes. It measures the tendency of one mol each of the binary complexes $\mathrm{MA}_{2}$ and $\mathrm{MB}_{2}$ to disproportionate forming two moles of MAB i.e.

$$
\mathrm{MA}_{2}+\mathrm{MB}_{2} \rightleftharpoons 2 \mathrm{MAB}, \mathrm{X}=\frac{[\mathrm{MAB}]^{2}}{\left[\mathrm{MA}_{2}\right]\left[\mathrm{MB}_{2}\right]}
$$




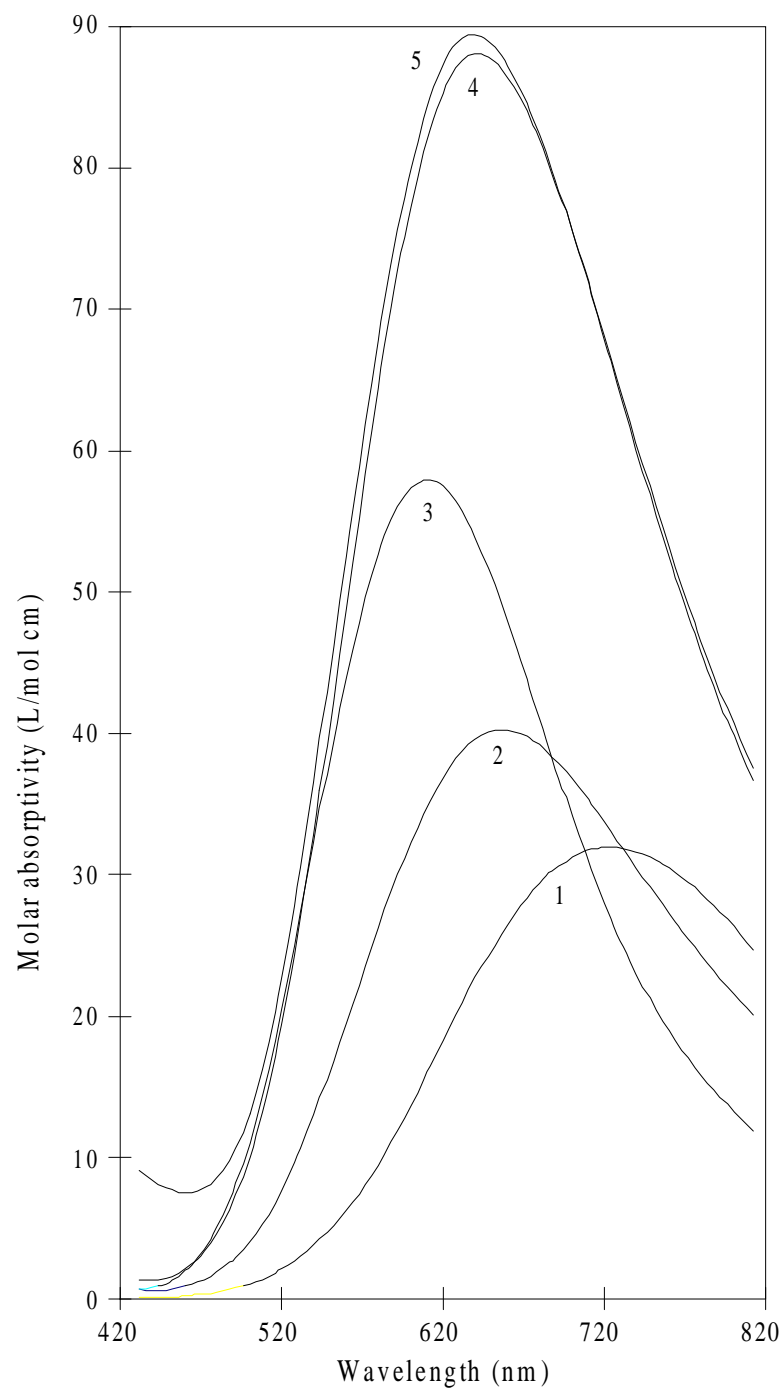

Figure 5. Calculated molar absorptivities of $\mathrm{Cu}$ (II)-histidine complexes. 1- $[\mathrm{Cu}(\mathrm{His}) \mathrm{H}]^{2+}, 2-[\mathrm{Cu}(\mathrm{His})]^{+}, 3-\left[\mathrm{Cu}(\mathrm{His})_{2} \mathrm{H}\right]^{+}, 4-\left[\mathrm{Cu}(\mathrm{His})_{2}\right], 5-$ $\left[\mathrm{Cu}(\mathrm{His})_{2} \mathrm{OH}\right]^{-}$.

It is therefore calculated by: $\log X=2 \log \beta_{\mathrm{MAB}}-(\log$ $\beta_{\mathrm{MA} 2}+\log \beta_{\mathrm{MB} 2}$ ). The value of the constant $\mathrm{X}$ expected on statistical grounds is 4 . Whenever it deviates from this value, it must be the result of intraligand electronic and/or steric interactions ${ }^{26}$.

Whenever possible, this parameter was calculated and the results are shown in Table 5, where it can be seen that it has always a value greater than the statistically expected one.

In our case, it seemed also relevant to calculate the equilibrium constant corresponding to the addition of ligand $\mathrm{B}$ to the 1:1 complex MA

$$
\mathrm{MA}+\mathrm{B} \rightleftharpoons \mathrm{MAB}, \mathrm{K}_{\mathrm{ad}}=\frac{[\mathrm{MAB}]}{[\mathrm{MA}][\mathrm{B}]}
$$

A constant corresponding to this reaction was calculated and is also shown in Table 5.

\section{$C u^{I I}$-acetohydroxamic acid mixed ligand complexes}

The value of $\log \mathrm{X}$ which is equal to 4.65 for $[\mathrm{Cu}(\mathrm{Aha})(\mathrm{Ha})]^{+}$is almost as large as the one found for the $\mathrm{Cu}^{\text {II }}$ mixed complex with histamine and pyrocatecholate, which is 4.86 under the same conditions ${ }^{27}$. The values of $\log \mathrm{X}$ for $[\mathrm{Cu}(\mathrm{Aha})(\mathrm{Gly})]$ and $[\mathrm{Cu}(\mathrm{Aha})(\mathrm{His})]$ are smaller, but still much larger than the statistically expected value, demonstrating a significant stabilization of these mixed ligand complexes.

The two mixed complexes with histamine and histidine have almost the same formation constant, while the binary $\left[\mathrm{Cu}(\mathrm{His})_{2}\right]$ complex $(\log \beta=18.220)$ is much more stable than the $\left[\mathrm{Cu}(\mathrm{Ha})_{2}\right]^{2+}(\log \beta=15.97)$. But while $\log \mathrm{X}$ of $[\mathrm{Cu}(\mathrm{Aha})(\mathrm{His})]$ is smaller than the one of $[\mathrm{Cu}(\mathrm{Aha})(\mathrm{Ha})]^{+}$, the value of $\mathrm{K}_{\mathrm{ad}}$ of $[\mathrm{Cu}(\mathrm{Aha})(\mathrm{His})]$ is greater than the one of $[\mathrm{Cu}(\mathrm{Aha})(\mathrm{Ha})]^{+}$. Therefore, the greater stabilization of $[\mathrm{Cu}(\mathrm{Aha})(\mathrm{Ha})]^{+}$, when compared to [Cu(Aha)(His)], can only be attributed to the greater stability of binary histidine complex, which must be destroyed in the disproportionation process that supposedly takes place to form the mixed ligand complex.

Both $[\mathrm{Cu}(\mathrm{Aha})(\mathrm{Gly})]\left(\lambda_{\max }=652 \mathrm{~nm}\right)$ and $[\mathrm{Cu}(\mathrm{Aha})$ $(\mathrm{Ha})]^{+}\left(\lambda_{\max }=624 \mathrm{~nm}\right)$ have foreseeable coordinations, shown in Structures 5 and 6. The same does not happen with the histidine complexes [Cu(Aha)(His)] $\left(\lambda_{\max }=624\right.$ $\mathrm{nm})$ and $[\mathrm{Cu}(\mathrm{Aha})(\mathrm{His}) \mathrm{OH}]^{-}\left(\lambda_{\max }=584 \mathrm{~nm}\right)$. However, considering the coincidence of $\lambda_{\max }$ of $[\mathrm{Cu}(\mathrm{Aha})(\mathrm{Ha})]^{+}$and [Cu(Aha)(His)], shown in Fig. 6, it seems reasonable to propose that both have the same co-ordination (shown in Structure 6), the carboxylate group of histidine remaining uncoordinated. As for the structure of $[\mathrm{Cu}(\mathrm{Aha})(\mathrm{His}) \mathrm{OH}]^{-}$ $\left(\lambda_{\max }=564 \mathrm{~nm}\right)$ it is probably similar to the one of [Cu(Aha)(His)], a proton being lost by the imidazol group of histidine, since both have similar spectra, as shown in Fig. 6.

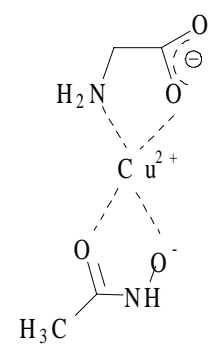

5

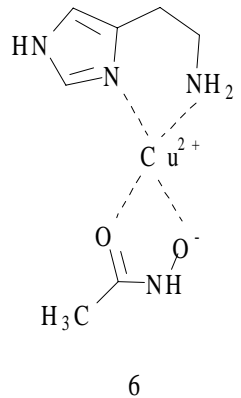

\section{$C u^{I I}$-glycinehydroxamic acid mixed ligand complexes}

In this case none of the structures is foreseeable, since while in the mixed complexes with Aha its co-ordination 


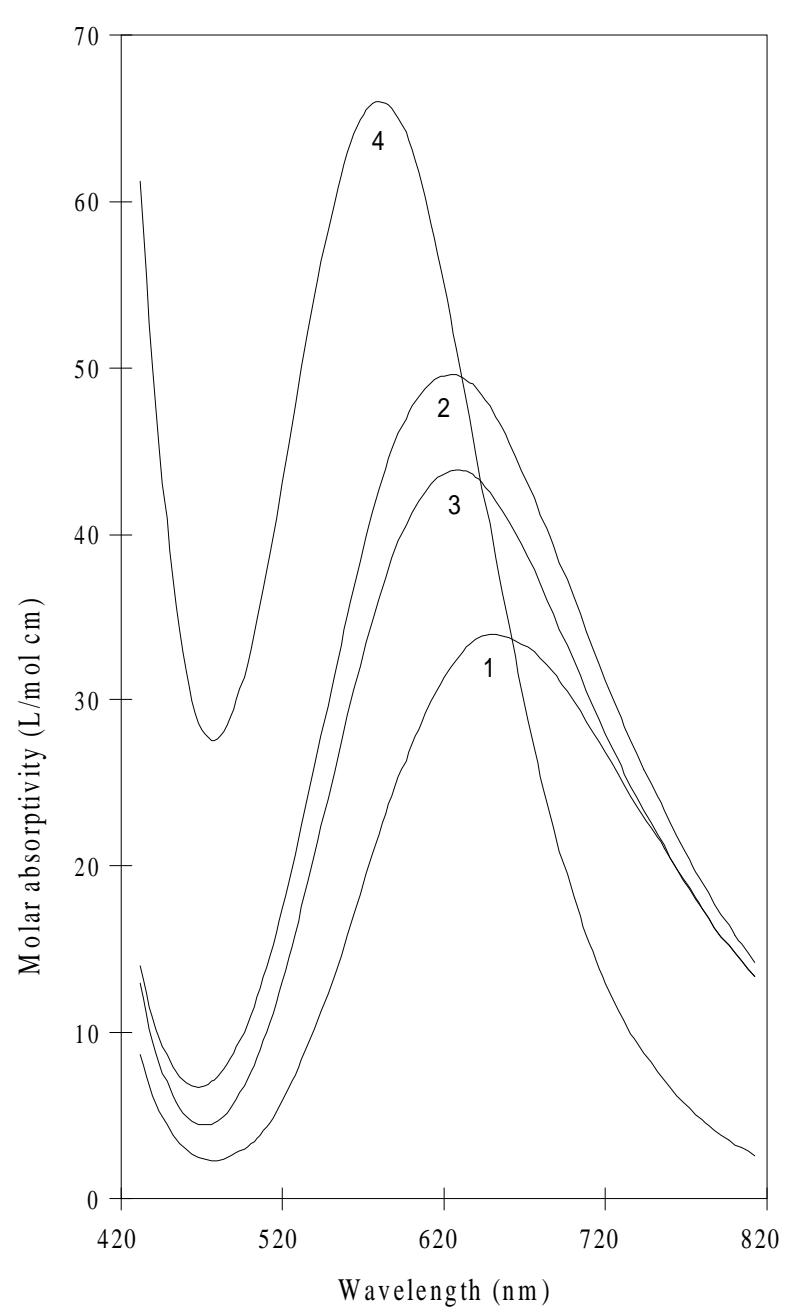

Figure 6. Calculated molar absorptivities of $\mathrm{Cu}(\mathrm{II})$-Aha-mixed complexes. 1- $[\mathrm{Cu}(\mathrm{Aha})(\mathrm{Gly})], 2-[\mathrm{Cu}(\mathrm{Aha})(\mathrm{Ha})]^{+}, 3-[\mathrm{Cu}(\mathrm{Aha})(\mathrm{His})], 4-$ $[\mathrm{Cu}(\mathrm{Aha})(\mathrm{His})(\mathrm{OH})]^{-}$.

must remain $\mathrm{O}, \mathrm{O}$, in the ones with Gha it could be co-ordinated either as a $\mathrm{O}, \mathrm{O}$ donor (like Aha) or as a $\mathrm{N}, \mathrm{N}$, donor like in its binary complexes with the $\mathrm{Cu}^{\mathrm{II}}$ ion $^{20 \mathrm{~b}}$. Therefore, starting with $[\mathrm{Cu}(\mathrm{Gha})(\mathrm{Gly})]\left(\lambda_{\max }=596 \mathrm{~nm}\right)$ there is always more than one possibility of co-ordination for the glycinehydroxamate anion. By comparison, $[\mathrm{Cu}(\mathrm{Gha})(\mathrm{Gly})]$ is much more stable than $[\mathrm{Cu}(\mathrm{Aha})(\mathrm{Gly})]$ and they evidently do not have the same structure, since their $\lambda_{\max }$ are quite different. Structure 7, in which Gha is $\mathrm{N}, \mathrm{N}$ co-ordinated, seems therefore the most probable one.

The Gha complexes with both histamine and histidine, with the exception of $[\mathrm{Cu}(\mathrm{Gha})(\mathrm{His}) \mathrm{H}]^{+}$, all have quite similar absorption spectra. They have formation constants larger than the corresponding complexes with Aha, but their values of $\log \mathrm{X}$, as well as of $\mathrm{K}_{\mathrm{ad}}$, are smaller. Evidently this is a result of a different co-ordination, since there is also a difference in the absorption spectra of $[\mathrm{Cu}(\mathrm{Gha})(\mathrm{Ha})]^{+}\left(\lambda_{\max }=564\right)$ when compared to

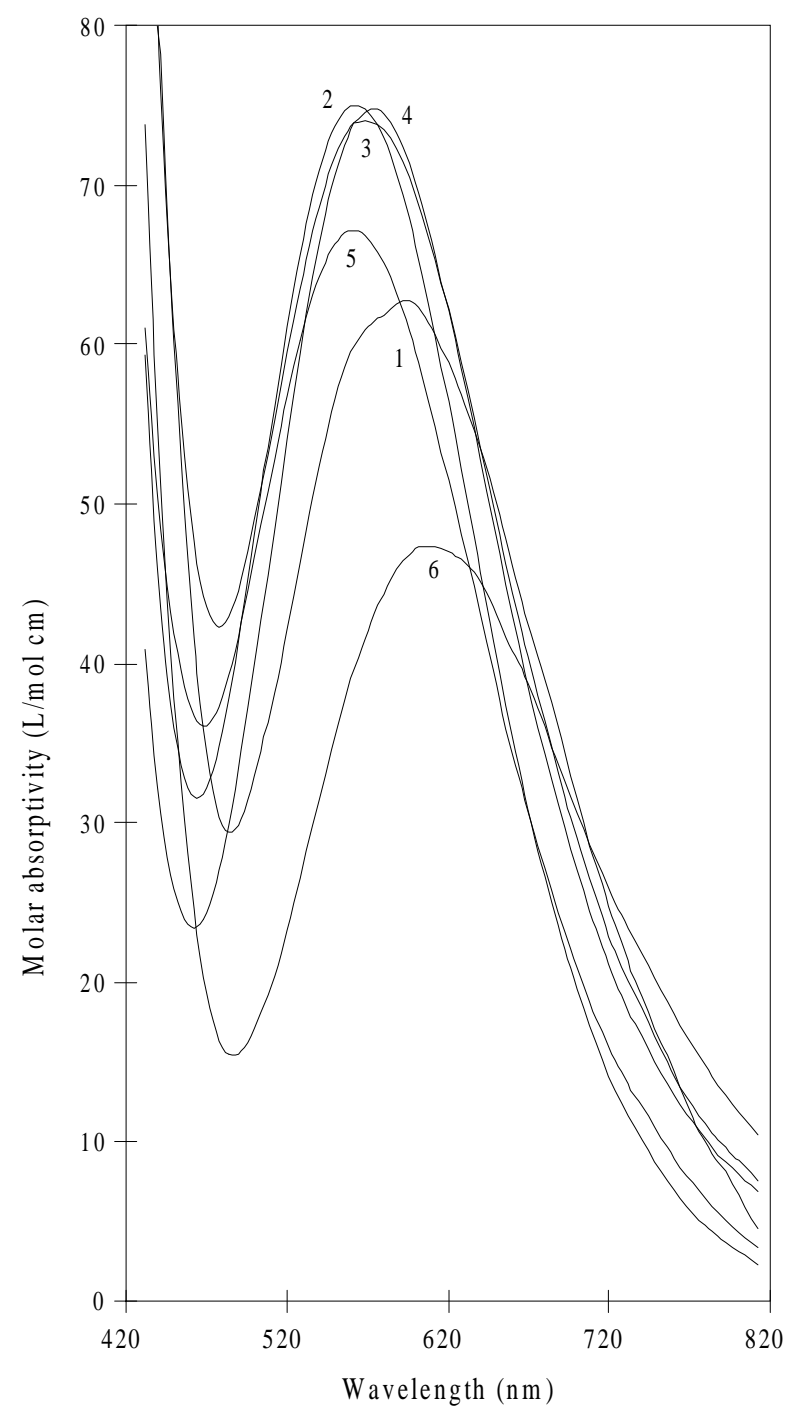

Figure 7. Calculated molar absorptivities of $\mathrm{Cu}(\mathrm{II})$-Gha-mixed complexes. 1- $[\mathrm{Cu}(\mathrm{Gha})(\mathrm{Gly})], 2-[\mathrm{Cu}(\mathrm{Gha})(\mathrm{Ha})]^{+}, 3-[\mathrm{Cu}(\mathrm{Gha})(\mathrm{Ha})(\mathrm{OH}], 4-$ $[\mathrm{Cu}(\mathrm{Gha})(\mathrm{His})], 5-[\mathrm{Cu}(\mathrm{Gha})(\mathrm{His})(\mathrm{OH})]^{-}, 6-[\mathrm{Cu}(\mathrm{Gha})(\mathrm{His})(\mathrm{H})]^{+}$.

$[\mathrm{Cu}(\mathrm{Aha})(\mathrm{Ha})]^{+}$and of $[\mathrm{Cu}(\mathrm{Gha})(\mathrm{His})]\left(\lambda_{\max }=572\right)$ when compared to $[\mathrm{Cu}(\mathrm{Aha})(\mathrm{His})]$. The smaller values of $\log \mathrm{X}$ can be explained as the result of a larger stability of the Gha-Cu ${ }^{\text {II }}$ binary complexes. Consequently, for these complexes the co-ordination shown in Structure 8 for $[\mathrm{Cu}(\mathrm{Gha})(\mathrm{Ha})]^{+}$is the most probable, in which the carboxy-
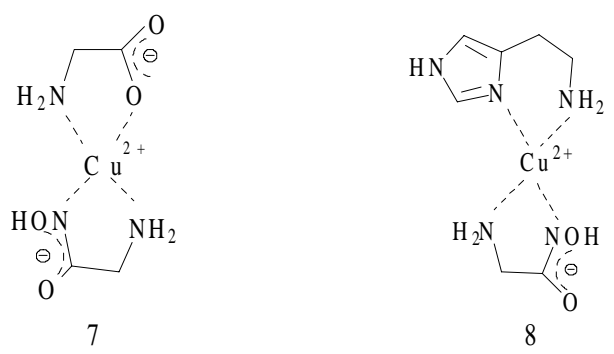
late group would be co-ordinated axially, to account for the small difference in $\lambda_{\max }$ in these two complexes.

The structure of $[\mathrm{Cu}(\mathrm{Gha})(\mathrm{His}) \mathrm{H}]^{+}\left(\lambda_{\max }=612 \mathrm{~nm}\right)$ probably has histidine co-ordinated glycine-like and Gha as in its binary complexes.

A final conclusion can be formulated as follows: $\mathrm{Cu}-$ hydroxamate complexes do not significantly favour mixed ligand complex formation with aminoacids having only the carboxylate and amino groups, however these complexes are strongly formed with histidine, due to the presence of the imidazol group.

\section{Acknowledgment}

The authors are grateful for financial support from Fundação de Amparo à Pesquisa do Estado de Minas Gerais (FAPEMIG), Conselho Nacional de Desenvolvimento Científico e Tecnológico (CNPq) and Financiadora de Estudos e Projetos (FINEP). During this work one of us $(\mathrm{MCF})$ received a maintenance grant from $\mathrm{CNPq}$.

\section{References}

1. Paniago, E.B.; Carvalho, S. Ciência e Cultura 1988, $40,629$.

2. Davidson, D.J. J. Chem. Ed. 1940, 17, 81.

3. Agrawal, Y.K. Rev .Anal. Chem. 1980, 5, 3.

4. Kurzak, B; Kozlowski, H.; Farkas, E. Coord. Chem. Rev 1992, 114, 169.

5. Farkas, E.; Szoke, J.; Kiss, T.; Kozlowzki, H.; Bal, W. J. Chem. Soc. Dalton Trans. 1989, 2247.

6. Sigel, H. In Metal ions in biological systems; Sigel, H., Ed.; Marcel Dekker; New York, v.2, 1973, p.63.

7. Sundberg, R.J.; Martin, R.B. Chemical Reviews 1974, $74,471$.

8. Wilson, E.W.; Kasperian, M. H.; Martin, R.B. J. Am. Chem. Soc. 1970, 92, 5365.

9. Pettit, L.D.; Swash, L.M. J. Chem. Soc., Dalton Trans. 1976, 588.

10. Camerman, N.; Fawcett, J.K.; Kruck, T.P.A.; Sarkar, B.; Camerman, A. J. Am. Chem. Soc. 1978, 100, 2690.

11. Sovago, I.; Kiss, T.; Gergely, A. J.Chem. Soc., Dalton Trans. 1978, 964.
12. Sarkar, B. In Metal ions in biological systems; Sigel, H., Ed.; Marcel Dekker; New York, v. 12, 1981, p. 233.

13. Patel, P.; Bhattacharya, P. K. J. Inorg. Biochem. 1994, 54, 187.

14. Flasckka, H.A. In EDTA Titrations - An Introduction to Theory and Practice, Pergamon Press, London, 1959, p. 78.

15. Molina, M; Melios, C.; Tognolli, J.O.; Luchiari, L.C.; Jafellici, J.R.M. J. Electroanal. Chem. 1979, 105, 237.

16. Duarte, H.A.; Paniago, E.B.; Carvalho, S.; Fernandes, M.C.; Yamaki, R.T. de Resumos - SBQ 1994, QA-119

17. Gans, P.; Sabatini, A.; Vacca, A. J. Chem. Soc., Dalton Trans. 1985, 1195.

18. (a) Leggett, D.J. Anal. Chem. 1977, 49, 276. (b) Leggett, D.J.; Kelly, S.L.; Shine, L.R.; Wu, Y.T.; Chang, D.; Kadish, M. Talanta 1983, 30, 579.

19. (a) Sillen, G. L.; Martell, A.E. Stability constants of metal complexes, The Chemical Society, Special Publication No. 25, Supplement No 1 to Special Publication No. 17; The Chemical Society: London, 1971. (b) Martell, A.E.; Smith, R. M. Critical Stability Constants v. 1. Amino Acids. Plenum Press: New York,. 1974.

20. (a)Paniago, E.B.; Carvalho, S. Inorg. Chim. Acta 1984, 92, 253.(b) Miranda-Pinto, C.O.; Paniago, E.B.; Tabak, M.; Carvalho, S.; Mascarenhas, Y.P. Inorg. Chim. Acta 1987, 137, 145. (c) Julien-Pouzol, M.; Jaulmes,. S.; Laruelle, P.; Carvalho, S.; Paniago, E.B. Acta Crystallog. 1985, C41, 712.

21. Bonnett, J.J.; Jeannin, Y. Acta Crystallogr., Sect. B 1970, 26, 318.

22. Wilson, E.W.; Kasperian, M.H.; Martin, R.B. J. Am. Chem. Soc. 1970, 92, 5365.

23. Evertsson, B. Acta Crystallogr. Sect. B. 1969, 25, 30.

24. Meyer, J.L.; Bauman, J.E. J. Am. Chem. Soc. 1970, 92, 4210.

25. Sigel, H.; McCormick, D.B. J. Am. Chem. Soc. 1971, 93, 2041.

26. Laurie, S.H.; James, C. Inorg. Chim. Acta, 1983, 78, 225.

27. Huber, P.R.; Griesser, R.; Prijs, B.; Sigel, H. Eur. J. Biochem. 1969, 10, 238. 